\title{
Impact of grazing by microzooplankton in the Northwest Arm of Halifax Harbour, Nova Scotia
}

\author{
D. J. Gifford* \\ Department of Oceanography, Dalhousie University, Halifax, Nova Scotia, Canada B3H 4J1
}

\begin{abstract}
Impact of grazing by natural assemblages of microzooplankton was measured in 5 in situ experiments in Halifax Harbour, Nova Scotia (Canada) using a seawater dilution method. The microzooplankton assemblages, dominated numerically by oligotrich ciliates, exerted a seasonally variable grazing impact; $38 \%$ of the initial standing stock of chlorophyll a $\mathrm{d}^{-1}$ was consumed $(=47 \%$ of potential chlorophyll production $\mathrm{d}^{-1}$ ) in June when flagellates $<12 \mu \mathrm{m}$ dominated the phytoplankton. No significant grazing occurred in November during a bloom of large diatoms. In March, when grazing and phytoplankton growth were in balance, $100 \%$ of the daily chlorophyll production was grazed. Assumptions of the dilution method that threshold feeding does not occur and that phytoplankton nutrients are not limiting were examined, and although probably violated in some cases, were found not to affect the results of the experiments.
\end{abstract}

\section{INTRODUCTION}

The microzooplankton size category $(<200 \mu \mathrm{m})$ is composed of a diverse taxonomic assemblage, including planktonic Protozoa and larval and naupliar stages of Metazoa. Two suborders of ciliate protozoans, the Tintinnina (tintinnids) and the Oligotrichina (oligotrichs) are ubiquitous and abundant in pelagic ecosystems, usually dominating the microzooplankton fauna Within the ciliate microzooplankton, aloricate forms primarily but not exclusively oligotrichs, inevitably outnumber the loricate tintinnids (e.g. Beers \& Stewart 1969a, 1970, Beers et al. 1975, 1980, Smetaček 1981). Some planktonic ciliates are capable of ingesting bacteria in certain environments (Sherr \& Sherr 1987), although bacterial abundances are insufficiently high in most pelagic environments to constitute a primary nutritional source (Fenchel 1980). Some forms, such as the haptorid ciliate Myrionecta (ex Mesodinium) rubra, are obligate autotrophs (Lindholm 1985), and some oligotrich ciliates retain functional chloroplasts and are mixotrophs (McManus \& Fuhrman 1986, Stoecker et al. 1987). However, it is generally agreed that most planktonic oligotrichines (= tintinnids \& oligotrichs), including the mixotrophic forms, are primarily herbivorous,

\footnotetext{
- Present address: Louisiana Universities Marine Consortium, Chauvin, Louisiana 70344, USA
}

consuming nano- and microphytoplankton (e.g. Beers \& Stewart 1970, 1971, Beers et al. 1975, 1980, Heinbokel 1978a, b. Smetaček 1981, Stoecker et al. 1981). Indirect estimates suggest that microzooplankton consume a substantial fraction of the phytoplankton production in pelagic food webs (e.g. Riley 1956, Beers \& Stewart 1970, 1971, Takahashi \& Hoskins 1978). However, the feeding biology of most microzooplankton taxa has not been examined directly and is not well known, causing uncertainty in appraisal of their trophic importance.

While several studies document feeding rates and prey preferences of tintinnids in laboratory culture (Heinbokel 1978a, Stoecker et al. 1981, Verity 1985), the generally more abundant oligotrichs have not been examined in similar detail. Methods to assess grazing rates of herbivorous ciliates in the laboratory involve monitoring ingestion of inert tracers, such as cornstarch particles (Spittler 1973, Heinbokel 1978b), or following changes in concentration of the organisms' algal food with time, either as cell numbers (Heinbokel 1978a, Stoecker et al. 1981, Verity 1985) or plant pigments (Gifford 1985a). Laboratory studies have the advantages that conditions of food level, media, food type and quality, and densities of consumers are specified by the experimenter. They have the disadvantage of uncertainty that the physiological rates measured represent the norm in nature. Rates measured in the 
laboratory may be overestimates of mean conditions in the field if experimental conditions are unrealistically advantageous to the consumers, or underestimates if conditions are stressful. The latter point is of concern when studying the delicate aloricate ciliates.

Field studies of microzooplankton grazing are confounded by the problem of manipulating small consumers whose size is the same order of magnitude as their food. A variety of approaches have been used, all of which have advantages as well as disadvantages (Table 1). Indirect methods have the advantage of being non-manipulative, and they suggest hypotheses to be tested directly. However, correlation of consumer-prey cycles observed in nature reveals only possible qualitative relationships. As noted above, extrapolation of laboratory results to the field is quantitative, but may not reflect in situ conditions. The first 4 direct methods listed in Table 1 are quasi in situ, involving manipulation, consequent alteration of the natural microplankton assemblage, and incubation. All have the advantage of being empirical. Methods which use tracers of ingestion, whether inert particles or radioisotopes, yield per capita rates of consumption and are usually of short duration in order to avoid internal recycling of the tracer. Because of the requisite short timescales, the organisms examined by tracer techniques may not be adapted to the experimental conditions, and may not behave or feed normally. Such methods demonstrate phagotrophic feeding unequivocally. However, in the case of tracer particles, selective feeding by the consumers may result in underestimation of consumption (e.g. Stoecker et al. 1981). Metabolic inhibitors are most useful for measuring eukaryotic consumption of prokaryotes, e.g. ciliate grazing of bacteria and cyanobacteria (Fuhrman \& McManus 1984, Campbell \& Carpenter 1986). They have not yet been applied successfully to eukaryoteeukaryote interactions, and may have unknown effects

Table 1. Summary of methods used to estimate the grazing impact of microzooplankton

\begin{tabular}{|c|c|c|c|}
\hline Method & Advantages & Disadvantages & Source \\
\hline \multicolumn{4}{|l|}{ Indirect methods } \\
\hline $\begin{array}{l}1 \text { Correlation of natural } \\
\text { consumer-prey cycles }\end{array}$ & Non-invasive & Qualitative & $\begin{array}{l}\text { Smetaček (1981), Sheldon et al. } \\
\text { (1986) }\end{array}$ \\
\hline $\begin{array}{l}2 \text { Extrapolation of labo- } \\
\text { ratory rates to the field }\end{array}$ & Non-invasive & $\begin{array}{l}\text { May not represent in situ } \\
\text { conditions }\end{array}$ & $\begin{array}{l}\text { Beers \& Stewart (1970, 1971), Ta- } \\
\text { guchi (1976), Heinbokel (1978b), } \\
\text { Rassoulzadegan \& Etienne } \\
\text { (1981), Burkill (1982), Rassoul- } \\
\text { zadegan (1982), Capriulo \& Car- } \\
\text { penter (1983), Hernroth (1983), } \\
\text { Cosper \& Stepien (1984), An- } \\
\text { dersen \& Sorensen (1986), Paran- } \\
\text { jape et al. (1985) }\end{array}$ \\
\hline $\begin{array}{l}3 \text { Extrapolation from } \\
\text { other field data }\end{array}$ & Non-invãsive & $\begin{array}{l}\text { Correlations may not reflect } \\
\text { natural relationships }\end{array}$ & $\begin{array}{l}\text { Riley (1956), Takahashi \& Hos- } \\
\text { kins (1978) }\end{array}$ \\
\hline \multicolumn{4}{|l|}{ Direct methods } \\
\hline $\begin{array}{l}1 \text { Tracers of ingestion } \\
\text { (A) Inert particles }\end{array}$ & $\begin{array}{l}\text { Quantitative; demonstrates } \\
\text { phagocytosis directly }\end{array}$ & $\begin{array}{l}\text { Selective feeding by consum- } \\
\text { ers may affect results }\end{array}$ & $\begin{array}{l}\text { Heinbokel \& Beers (1979), Børs- } \\
\text { heim (1984) }\end{array}$ \\
\hline (B) Radioisotopes & Quantitative, sensitive & $\begin{array}{l}\text { Alternate pathways of isotope } \\
\text { uptake affect cycling of tracer; } \\
\text { highly manjpulative }\end{array}$ & Lessard \& Swift (1985) \\
\hline 2 Metabolic inhibitors & Quantitative & Non-specificity of inhibitors & Campbell \& Carpenter (1986) \\
\hline 3 Size fractionation & $\begin{array}{l}\text { Quantitative; uses natural } \\
\text { assemblage }\end{array}$ & $\begin{array}{l}\text { No true controls; highly mani- } \\
\text { pulative } \text {; predators \& prey are } \\
\text { not unequivocally separated }\end{array}$ & $\begin{array}{l}\text { Capriulo \& Carpenter (1980), } \\
\text { Verity (1986) }\end{array}$ \\
\hline 4 Seawater dilution & $\begin{array}{l}\text { Quantitative simultaneous } \\
\text { estimation of algal growth \& } \\
\text { mortality; minimally mani- } \\
\text { pulative to natural assem- } \\
\text { blage }\end{array}$ & $\begin{array}{l}\text { May alter natural assemblage; } \\
\text { unproven assumption that } \\
\text { feedung thresholds do not } \\
\text { occur }\end{array}$ & $\begin{array}{l}\text { Landry \& Hassett (1982), Burkill } \\
\text { et al. (1987), Paranjape (1987) }\end{array}$ \\
\hline 5 Pigment budget & $\begin{array}{l}\text { In situ; no manipulation of } \\
\text { natural assemblage }\end{array}$ & $\begin{array}{l}\text { Uncertainty of conversion effi- } \\
\text { ciency of chlorophyll to } \\
\text { phaeopigments }\end{array}$ & $\begin{array}{l}\text { SooHoo \& Kiefer (1982), } \\
\text { Welschmeyer \& Lorenzen (1985) }\end{array}$ \\
\hline
\end{tabular}


on the organisms they are not intended to inhibit (Sherr et al. 1986, Taylor \& Pace 1987, Tremaine \& Mills 1987). Studies employing size fractionation or dilution are of longer duration than studies which use tracers, and yield assemblage, rather than per capita, grazing rates. Size fractionation techniques assume that control and experimental treatments are the same with respect to prey species composition, size, and abundance. In addition to altering the assemblage, so that the growth environment of prey populations may not be equivalent in the different fractions, these techniques are particularly destructive to the aloricate ciliates which usually dominate the microzooplankton (Gifford 1985b). One direct method, the pigment budget, is a true in situ method which does not require manipulation of the microzooplankton and their prey. However, because of uncertainty about the conversion efficiency of chlorophyll to phaeopigments (Conover et al. 1986, Klien et al. 1986, Wang \& Conover 1986, Kiørboe \& Tiselius 1987), the true quantitative power of this approach remains to be demonstrated.

In this study, I employed the seawater dilution method (Landry \& Hassett 1982). This method uses natural assemblages of microzooplankton organisms and their food. Because seawater is diluted, rather than size-fractionated or concentrated, manipulation of delicate organisms is minimized. The experiments, which follow changes in chlorophyll concentration over experimental duration, are simple in concept and execution. The method is discussed in detail below

\section{METHODS}

The dilution method. The dilution technique expresses change in phytoplankton concentration with time by

or

$$
P_{t}=P_{o} e^{(k-g)}
$$

$$
1 / t \ln \left(\mathrm{P}_{\mathrm{t}} / \mathrm{P}_{\mathrm{o}}\right)=\mathrm{k}-\mathrm{g}
$$

where $\mathrm{P}_{\mathrm{o}}$ and $\mathrm{P}_{t}=$ phytoplankton densities at the beginning and end of the experiment; $\mathrm{k}=$ algal growth coefficient; $g=$ coefficient of algal mortality due to grazing; $t=$ time (cf. Frost 1972). Values of $\mathrm{k}$ and $\mathrm{g}$ are calculated from changes in phytoplankton density following incubations of different dilutions of seawater containing the natural microzooplankton assemblage. The term $1 / t \ln \left(\mathrm{P}_{t} / \mathrm{P}_{0}\right)$ is the apparent phytoplankton growth rate'. The y-intercept of this relationship is the 'true' phytoplankton growth rate, $k$, in the absence of grazers. The negative slope of the line is the grazing coefficient, $g$ (Fig. 1A). Because grazers are diluted with their food, the observed rate of change in chlorophyll is linearly related to the dilution factor (fraction of unfiltered seawater).

The method requires 3 assumptions, discussed in some detail by Landry \& Hassett (1982): first, that phytoplankton growth rates are not density-dependent; second, that ingestion is a linear function of consumer density; third, that Equation (1) describes phytoplankton growth adequately. The first assumption implies that nutrient levels in the dilution treatments are not limiting for the duration of the experiment. The second assumption requires that feeding thresholds do not occur at dilute food levels (cf. Frost 1972, Lam \& Frost 1976), and conversely, that feeding does not saturate at high food levels. In the latter case microzooplankton grazing will be underestimated; in the former it will be overestimated (Fig. 1B, C).

Experimental design. I conducted 5 experiments in Halifax Harbour during 1984-85. All experiments were done from a shore station on the Northwest Arm of the harbour, where $z=2 \mathrm{~m}$ at high tide. The experiments were performed at different seasons so that a range of physical and ecological conditions would be encountered (Table 2). The Northwest Arm of the harbour is an ideal locale to study microzooplankton: the fauna is dominated by high standing stocks of aloricate ciliates during most of the year, with a species assemblage similar to that of the Scotian Shelf (Johansen 1976).

Seawater was collected from $z=1.5 \mathrm{~m}$ and poured gently through a submerged $102 \mu \mathrm{m}$ mesh. Although some of the aloricate ciliates are destroyed by passage through mesh (Gifford 1985a, b), this procedure is necessary to separate the protozoan microzooplankton from larger Metazoa, particularly copepod nauplii, whose feeding activity may obscure the protozoan grazing signal. The seawater was diluted by factors of $0,25,50,75,85$, and $95 \%$ with seawater collected from
Fig. 1 The dilution model (A) under conditions of feeding thresholds (B) and nutrient limitation (C)
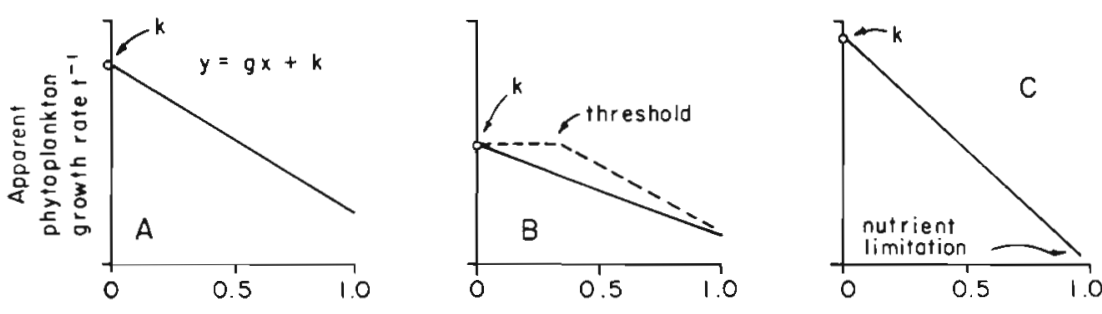

Fraction unfiltered seawater 
the same source and passed through a Whatman GF/F filter (cf. Li \& Dickie 1985); $100 \%$ dilutions were done as control treatments. I did not add excess phytoplankton nutrients (cf. Landry \& Hassett 1982) to the dilution treatments because such additions may result in substantial losses of oligotrich ciliates (Landry \& Hassett 1982, Gifford unpubl.).

Triplicate $100 \mathrm{ml}$ samples were taken from each treatment at the beginning of each experiment, collected on Whatman GF/F filters, and frozen for subsequent chlorophyll analysis. A single $300 \mathrm{ml}$ sample from each treatment was preserved with $20 \%(\mathrm{v} / \mathrm{v})$ acid Lugols solution (Throndsen 1978) for microzooplankton enumeration. Five replicates of each treatment were siphoned gently into $250 \mathrm{ml}$ polycarbonate flasks. The flasks were sealed with parafilm, capped, and incubated in situ at $z=1.5 \mathrm{~m}$ on a transparent plexiglass rack. In situ incubations were done to minimize changes in chlorophyll per cell which may occur following changes in light regime (Prezélin 1976, Perry et al. 1981) and to expose the phytoplankton to ambient light levels. The rack was retrieved after $24 \mathrm{~h}$ and chlorophyll and microzooplankton were sampled. In the 30 August and 13 November experiments, $100 \mathrm{ml}$ subsamples were collected from each of 4 replicates for chlorophyll analyses, and the 5th replicate was preserved with acid Lugols solution for microzooplankton enumeration. In the remaining 3 experiments, $100 \mathrm{ml}$ was collected from all replicates and the remaining ca $150 \mathrm{ml}$ preserved for microzooplankton enumeration.

Chlorophyll analysis. Extracted chlorophyll $190 \%$ acetone with grinding) was analyzed semi-automatically by fluorometry (Strickland \& Parsons 1972) using a Turner Designs Model 10 fluorometer interfaced with a Hewlett-Packard 9845 computer.

Microzooplankton enumeration. Of the preserved samples 50 to $100 \mathrm{ml}$ were settled for $24 \mathrm{~h}$ and the microzooplankton of the entire chamber bottom were counted and measured using an inverted microscope. Microzooplankton, exclusive of heterotrophic flagellates, were identified to the highest possible level of taxonomic separation. Oligotrichs were identified to genus (Fauré-Fremiet 1924, Kahl 1932) and were categorized by body size and geometry (Beers et al. 1975). Tintinnids were identified to species (Marshall 1969). Other ciliate Protozoa were identified to family or genus (Borror 1973, Corliss 1979). Herbivorous thecate dinoflagellates, such as Protoperidinium (Lessard 1984), were rare in all experiments and were not enumerated. Smaller herbivorous zooflagellates, while undoubtedly present (Goldman \& Caron 1985), were not distinguished by the fixation technique and were not enumerated, although their grazing activity is included in estimates of the impact of the total microzooplankton assemblage.
Data analysis. Data were analyzed by linear regression of apparent phytoplankton growth rate against dilution factor. Equation (1) was solved for $\mathrm{k}$ and $\mathrm{g}$, and $95 \%$ confidence intervals were calculated for these estimates. The hypothesis that $\mathrm{g}=0$ was tested for each curve. Tests for significance were done according to Sokal \& Rohlf (1981) at a level of $p<0.05$.

The assumption that nutrient limitation did not occur was evaluated by eliminating the undiluted treatments, where limitation is expected to occur, from the linear regression, recalculating $\mathrm{k}$ and $\mathrm{g}$, and testing for significant differences in these coefficients between the complete and altered data sets. The assumption that feeding thresholds were not present was addressed as follows: if measurable thresholds were present, the plots of apparent phytoplankton growth versus dilution factor would be inflected (Fig. 1B) and the method would overestimate microzooplankton grazing impact. Apparent thresholds were evaluated by decomposing the curves into 2 intersecting straight lines around a critical concentration' of chlorophyll (cf. Frost 1972). k, g and the correlation coefficient were calculated for the ascending portion of each curve, and compared for significance with the same values calculated from the entire data set.

\section{RESULTS}

\section{The microzooplankton assemblage}

The microzooplankton assemblage $<102 \mu \mathrm{m}$ was dominated by aloricate ciliates, primarily oligotrichs. Tintinnids were present in 4 of the 5 experiments but did not account for more than $22 \%$ (mean $=9 \%$ ) of summed aloricate ciliates and tintinnids during any experiment (Table 2). These organisms, along with miscellaneous non-oligotrichine aloricate ciliates and large heterotrophic Gymnodinium sp., constituted the predominant herbivorous microzooplankton. The obligate autotroph Myrionecta rubra and the carnivorous Didinium sp. were also present in some of the assemblages.

\section{Grazing impact of the microzooplankton assemblage}

The impact of grazing varied among the 5 experiments. The slopes $(=g)$ of all except the 13 November curves differed significantly from 0 (Table 3A, Fig. 2). The algal growth coefficient ranged from $0.01 \mathrm{~h}^{-1}$ in November to $0.07 \mathrm{~h}^{-1}$ in June $\left(=0.24\right.$ to $\left.1.68 \mathrm{~d}^{-1}\right)$, equivalent to 0.4 to 2.4 doublings $\mathrm{d}^{-1}$ The amount of chlorophyll grazed varied among the 5 experiments; 0 to $50.0 \%($ mean $=26.2 \%)$ of the initial standing stock was consumed per day, equivalent to 0 to $100.0 \%$ (mean $=49.3 \%$ ) of the daily chlorophyll pro- 
Table 2. Initial experimental conditions

\begin{tabular}{|c|c|c|c|c|c|c|c|c|c|}
\hline Date & $\begin{array}{c}\text { Tempera- } \\
\text { ture } \\
\left({ }^{\circ} \mathrm{C}\right)\end{array}$ & $\begin{array}{c}\text { Chl } a \\
\left(\mu \mathrm{g} l^{-1}\right)\end{array}$ & $\begin{array}{c}\text { Tintinnids } \\
\text { (Number } \\
1^{-1} \text { ) }\end{array}$ & $\begin{array}{c}\text { Oligotrichs } \\
\text { (Number } \\
\left.\mathrm{I}^{-1}\right)\end{array}$ & $\begin{array}{c}\text { Mis- } \\
\text { cellaneous } \\
\text { aloricate } \\
\text { ciliates } \\
(\text { Number } \\
\left.1^{-1}\right)\end{array}$ & $\begin{array}{c}\text { Myrionecta } \\
\text { rubra } \\
\text { (Number } \\
1^{-1} \text { ) }\end{array}$ & $\begin{array}{c}\text { Didinium } \\
\text { (Number } \\
\mathrm{l}^{-1} \text { ) }\end{array}$ & $\begin{array}{c}\text { Gym- } \\
\text { nodinium } \\
\text { (Number } \\
\left.1^{-1}\right)\end{array}$ & $\begin{array}{l}\text { Dominant } \\
\text { phytoplankton }\end{array}$ \\
\hline 30 Aug 84 & 20.0 & 1.9 & 320 & 7320 & 0 & 2880 & 0 & 0 & Flagellates 3 to $12 \mu \mathrm{m}$ \\
\hline 13 Nov 84 & 10.0 & 2.2 & 1440 & 11360 & 0 & 1960 & 440 & 0 & $\begin{array}{l}\text { Diatoms }>20 \mu \mathrm{m} \\
\text { Dinoflagellates }>30 \mu \mathrm{m}\end{array}$ \\
\hline 11 Mar 85 & 2.0 & 0.3 & 0 & 11080 & 0 & 0 & 0 & 0 & $\begin{array}{l}\text { Diatoms }>20 \mu \mathrm{m} \\
\text { Dinoflagellates }>25 \mu \mathrm{m}\end{array}$ \\
\hline 15 Apr 85 & 5.0 & 1.8 & 120 & 2680 & 340 & 0 & 220 & 0 & $\begin{array}{l}\text { Flagellates } 5 \text { to } 12 \mu \mathrm{m} \\
\text { Diatoms } \sim 20 \mu \mathrm{m}\end{array}$ \\
\hline 5 Jun 85 & 14.5 & 1.8 & 1280 & 5680 & 120 & 0 & 0 & 2460 & $\begin{array}{l}\text { Diatoms } \sim 5 \mu \mathrm{m} \\
\text { Dinoflagellates } \sim 12 \mu \mathrm{m}\end{array}$ \\
\hline
\end{tabular}

Fig. 2. Results of dilution experiments done in Halifax Harbour during 1984-1985

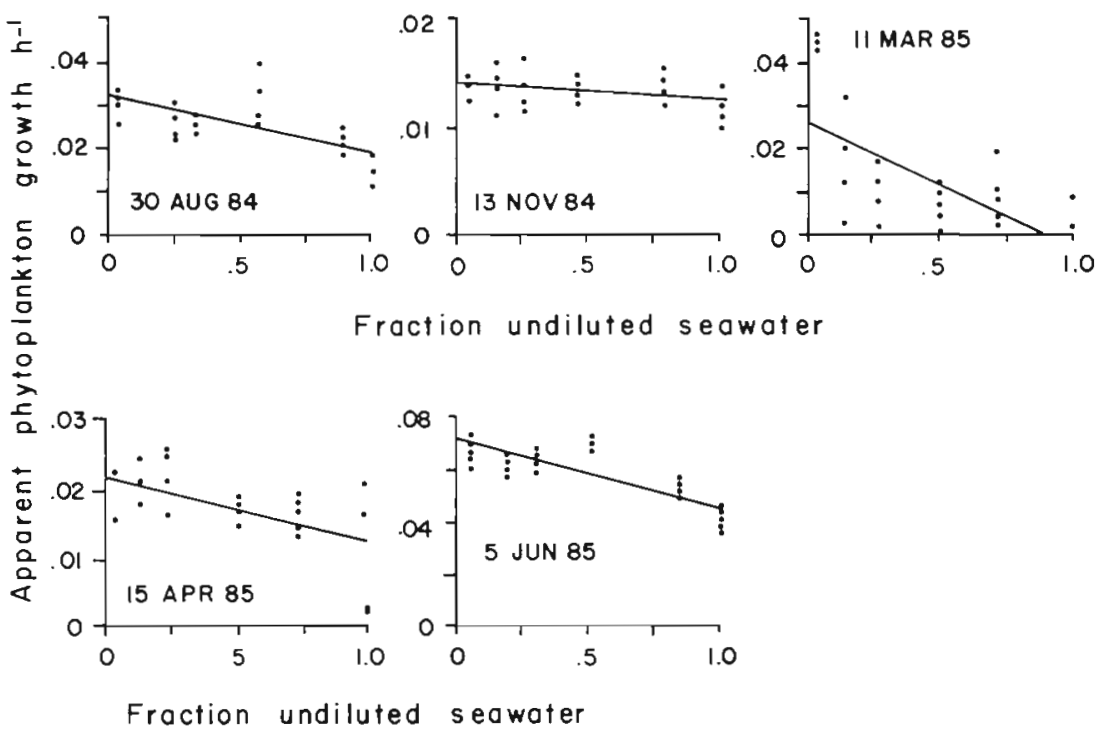

duction. In March $\mathrm{k}=\mathrm{g}$, suggesting that microzooplankton grazing and phytoplankton growth were in balance (Table 4).

Nutrient limitation does not appear to have occurred in any of the experiments. When the 5 data sets were analyzed without the undiluted treatments, neither the algal growth coefficient nor the grazing coefficient changed significantly (Table 3B), although the correlation coefficient of the 30 August experiment became insignificant, probably as a result of the reduced sample size of the altered data set.

Two of the 5 dilution curves ( 30 Aug and 5 Jun) could be decomposed into 2 intersecting straight lines to show apparent feeding thresholds. However, values of $\mathrm{k}, \mathrm{g}$, and $\mathrm{r}$ calculated for the ascending portions of these curves did not differ significantly from those obtained by linear regression of the entire data sets (Table 3C), indicating that feeding thresholds, if present, were not resolved by the dilution method and did not alter the results.

\section{DISCUSSION}

The seawater dilution technique is a straightforward, powerful, quasi in situ method which estimates algal growth and mortality due to grazing simultaneously. The method yields a bulk grazing estimate for complex natural assemblages of microplankton, and appears to be robust despite probable violations of its assumptions concerning feeding thresholds and nutrient limitation.

A potentially more troublesome problem was recog- 
Table 3. Linear regression of apparent phytoplankton growth versus dilution factor. $\mathrm{k}=$ algal growth coefficient; $\mathrm{g}=$ grazing coefficient; $r=$ correlation coefficient. Means with $95 \%$ confidence intervals. (A) Entire data sets; (B) test for nutrient limitation; (C) test for feeding thresholds; (D) test for effect of differential dilution of chlorophyll and aloricate ciliates

\begin{tabular}{|c|c|c|c|}
\hline Date & $k h^{-1}$ & $g h^{-1}$ & $|r|$ \\
\hline \multicolumn{4}{|l|}{ (A) } \\
\hline 30 Aug 84 & $0.03 \pm 0.004$ & $0.01 \pm 0.01^{\circ}$ & $0.63 \pm 0.38 \cdots$ \\
\hline 13 Nov 84 & $0.01 \pm 0.001$ & $0.001 \div 0.002$ & $0.28 \pm 0.34$ \\
\hline 11 Mar 85 & $0.03 \pm 0.001$ & $0.03 \pm 0.02^{\circ}$ & $0.60 \pm 0.37 \cdots$ \\
\hline 15 Apr 85 & $0.02 \pm 0.004$ & $0.01 \pm 0.01^{\circ}$ & $0.55 \pm 0.34 \cdots$ \\
\hline 5 Jun 85 & $0.07 \pm 0.004$ & $0.02 \pm 0.01^{\circ}$ & $0.82 \pm 0.32 \cdots$ \\
\hline \multicolumn{4}{|l|}{ (B) } \\
\hline 30 Aug 84 & $0.03 \pm 0.01$ & $0.01 \pm 0.01^{\circ}$ & $0.29 \pm 0.50$ \\
\hline 13 Nov 84 & $0.01 \pm 0.01$ & $-0.001 \pm 0.002$ & $0.17 \pm 0.52$ \\
\hline 11 Mar 85 & $0.04 \pm 0.02$ & $0.06 \pm 0.03^{\circ}$ & $0.63 \pm 0.44^{\cdots}$ \\
\hline 15 Apr 85 & $0.02 \pm 0.004$ & $0.01 \pm 0.01^{\circ}$ & $0.38 \pm 0.42 \cdots$ \\
\hline 5 Jun 85 & $0.07 \pm 0.01$ & $0.01 \pm 0.01^{\circ}$ & $0.65 \pm 0.42 \cdots$ \\
\hline \multicolumn{4}{|l|}{ (C) } \\
\hline 30 Aug 84 & $0.04 \pm 0.01$ & $0.02 \pm 0.03^{\circ}$ & $0.64 \pm 0.55 \cdots$ \\
\hline 5 Jun 85 & $0.08 \pm 0.02$ & $0.04 \pm 0.01^{\circ}$ & $0.88 \pm 0.42 \cdots$ \\
\hline \multicolumn{4}{|l|}{ (D) } \\
\hline 11 Mar 85 & $0.04 \pm 0.02$ & $0.06 \pm 0.03^{\circ}$ & $0.63 \pm 0.44 \cdots$ \\
\hline 5 Jun 85 & $0.07 \pm 0.01$ & $0.01 \pm 0.01^{\circ}$ & $0.65 \pm 0.42 \cdots$ \\
\hline
\end{tabular}

nized a posteriori. In the course of setting up the dilution treatments for the 5 experiments, gentle manipulation of seawater resulted in differential dilution of chlorophyll and aloricate ciliates (Table 5). Initial losses of ciliates can be attributed to handling (Table 5, Column 3). However, the achieved dilutions of ciliates over the duration of the experiments represent the combined effects of handling, ciliate population growth, and predator-prey interactions between the ciliates and their microzooplankton consumers (Table 5, Columns 4 and 5). The incubation bottles contained complex assemblages of microorganisms, including a number of carnivorous forms such as Didinium sp., Condylostoma sp., and an unidentified ampheleptid ciliate. The feeding biology of these organisms is not well known, although oligotrichs themselves may practice cannibalism (Gifford 1985b). The largest losses of aloricate ciliates occurred in the undiluted $(0 \%)$ treatments where the greatest possibility for predator-prey interactions existed. To evaluate the effect of differential dilution of chlorophyll and ciliates on the results, the dilution curves were recalculated without treatments involving mean losses in excess of $20 \%$ over experimental duration. This interval was chosen because the coefficient of variation of the microzooplankton counting method is 10 to $20 \%$. Using this criterion, the raw data of the 11 March and 5 June experiments were recalculated excluding the undiluted treatments. This is the same test as for the effect of nutrient limitation, and gave the same result: no significant changes in $\mathrm{k}, \mathrm{g}$, or $\mathrm{I}$ (Table 3D). Thus, losses of aloricate ciliates due to handling and trophic processes within the incubation bottles do not affect the results.

The experiments demonstrate that the impact of grazing by microzooplankton can be significant. While the limited data collected over the annual cycle render detailed analyses difficult, seasonal trends were evident. The greatest grazing impact occurred in March at the beginning of a diatom bloom, when the standing stock of chlorophyll was low and ciliate abundance was high. It is probable that the large, spinose, and chainforming diatoms present at this time were unavailable to the ciliates due to morphological constraints (Gifford et al. 1981, Verity \& Villareal 1986). However, thecate dinoflagellates $>25 \mu \mathrm{m}$ which were also present should have been an acceptable, if not preferred, food source (Stoecker et al. 1981, Gifford 1985b, Burkill et al. 1987). The impact of grazing was lower in April, on the trailing edge of the diatom bloom. In contrast, grazing impact was insignificant in November during a bloom of large diatoms. Interestingly, ciliate stocks were high at this time.

Table 4. Summary of experimental results

\begin{tabular}{|c|c|c|c|c|c|c|}
\hline Date & $\begin{array}{c}\text { Initial standing } \\
\text { stock chlorophyll } \\
\left(\mu \mathrm{g} \mathrm{l}^{-1}\right)\end{array}$ & $\begin{array}{l}\text { Chlorophyll } \\
\left.\text { (doublings } d^{-1}\right)^{a}\end{array}$ & $\begin{array}{l}\text { Potential produc- } \\
\text { tion chlorophyll } \\
\qquad\left(\mu g 1^{-1}\right)\end{array}$ & $\begin{array}{l}\text { Actual produc- } \\
\text { tion chlorophyll } \\
\left(\mu g \mathrm{I}^{-1}\right)\end{array}$ & $\begin{array}{l}\text { Initial standing } \\
\text { stock grazed } \mathrm{d}^{-1} \\
(\%)\end{array}$ & $\begin{array}{c}\text { Potential produc- } \\
\text { tion grazed } \mathrm{d}^{-1} \\
(\%)\end{array}$ \\
\hline 30 Aug 84 & 1.9 & 1.0 & 2.0 & 1.2 & 21.6 & 40.0 \\
\hline 13 Nov 84 & 2.2 & 0.4 & 0.6 & 0.5 & ns & ns \\
\hline 11 Mar 85 & 0.3 & 1.0 & 0.3 & 0.0 & 50.0 & 100.0 \\
\hline 15 Apr 85 & 1.8 & 0.7 & 1.1 & 0.5 & 21.1 & 54.5 \\
\hline 5 Jun 85 & 1.8 & 2.4 & 7.9 & 4.2 & 38.3 & 46.8 \\
\hline
\end{tabular}


Table 5. Expected and achieved dilution factors of chlorophyll and aloricate ciliates

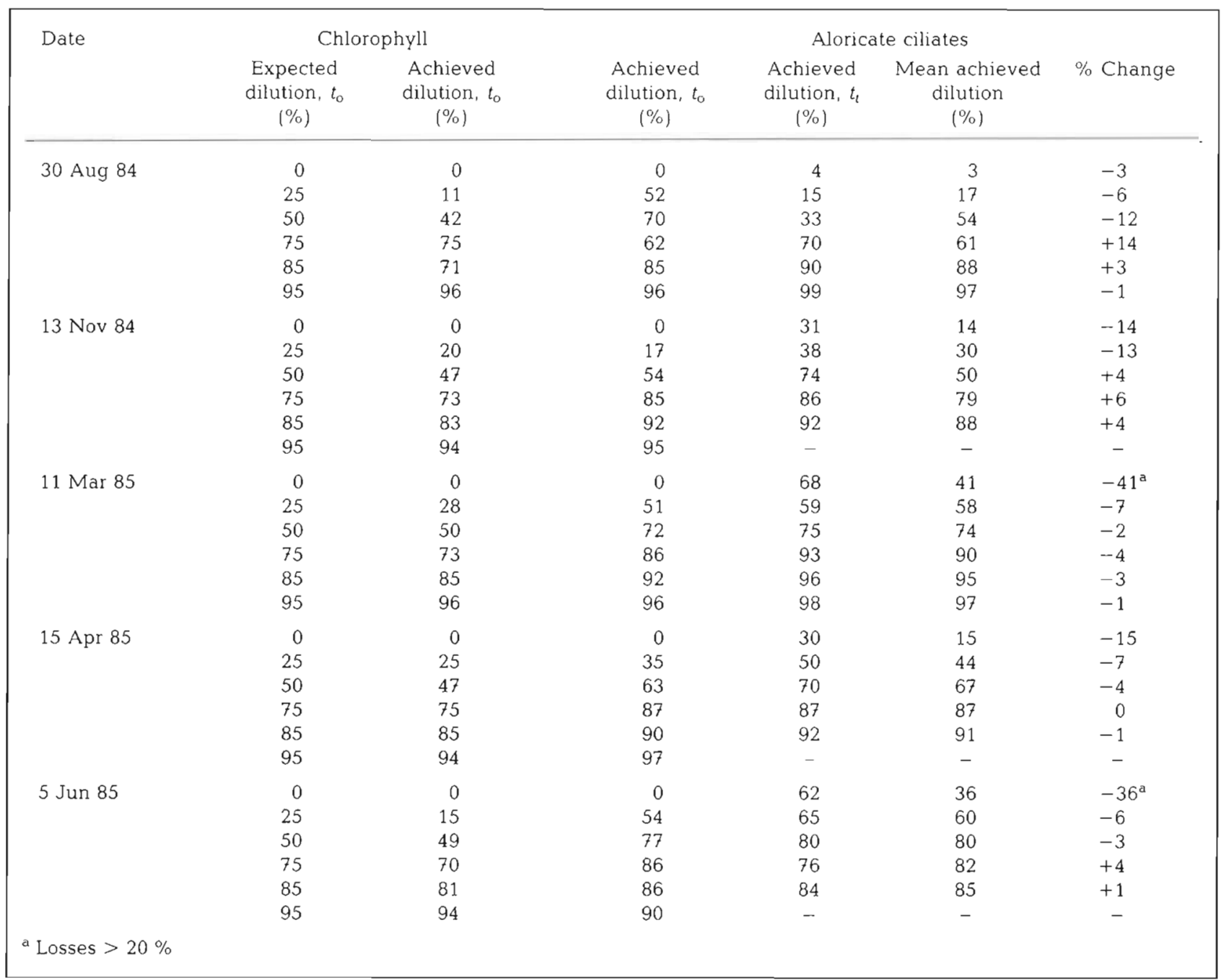

The results of this study agree with other estimates of the proportion of daily phytoplankton production consumed in the euphotic zones of coastal waters by microzooplankton (Table 6). The experiments described herein were designed to examine grazing by a particular size fraction of the zooplankton in the absence of their predators (e.g. omnivorous copepods) and some of their possible competitors (metazoan nauplii). The results demonstrate that the potential impact of the microzooplankton can be considerable: as much as $100 \%$ of the chlorophyll production may be transferred into the microzooplankton on a daily basis.

Given the high growth efficiencies reported for tintinnids (Heinbokel 1978a, Verity 1985) and oligotrichs (Gifford 1985a), a significant portion of the primary production consumed by these organisms should be available to higher order consumers which cannot feed efficiently on small phytoplankton (Nival \& Nival 1976, Bartram 1980) but which can consume ciliate-sized particles (Robertson 1983, Turner \& Anderson 1984, Stoecker \& Sanders 1985, Stoecker \& Egloff 1987, Gifford \& Dagg 1988). However, because the dominant oligotrich ciliates are capable of ingesting relatively large cells (Smetaček 1981, Gifford 1985b), they may additionally complicate the trophic structure of pelagic webs by competing with their predators for algal food items.

Acknowledgements. This research fulfills part of the requirements for the degree of Doctor of Philosophy from Dalhousie University. I was supported by grants from the Natural Sciences and Engineering Research Council of Canada to C. M. Boyd and by a Dalhousie Graduate Fellowship. I thank C. M. Boyd, J. D. Ives, N. B. Sharp and M. McInerney-Northcott for assistance in the field, the E. Morgan family of Halifax for the use of their elegant dock; and C. M. Boyd, J. A. Runge, and especially M. A. Paranjape for helpful discussion. Critical reviews by R. J. Conover, M. R. Landry, M. R. Lewis, D. K. Stoecker, P. G. Verity and an anonymous referee greatly improved the manuscript. NSF grant OCE 8613892 and the Louisiana Universities Marine Center assisted with publication. 
Table 6. Summary of studies of microzooplankton grazing in neritic environments. WC $=$ water column; EF $=$ extrapolation from field data; $\mathrm{EL}=$ extrapolation from laboratory data; $\mathrm{SF}=$ size fractionation; $\mathrm{SD}=$ seawater dilution

\begin{tabular}{|c|c|c|c|c|c|c|}
\hline Location & Taxon & $Z(m)$ & Season & Method & $\begin{array}{l}\text { Primary production } \\
\text { consumed }(\%)\end{array}$ & Source \\
\hline Long Island Sound & $\begin{array}{l}\text { Total } \\
\text { microzooplankton }\end{array}$ & WC & Annual & $E F$ & $43 \mathrm{yr}^{-1}$ & Riley (1956) \\
\hline Coastal Peru & Ciliates & WC & Jun & EL & $5-24 d^{-1}$ & Beers et al. (1971) \\
\hline California Current & $\begin{array}{l}\text { Total } \\
\text { microzooplankton }\end{array}$ & WC & Apr-Sep & EL & $7-52 d^{-1}$ & Beers \& Stewart (1970) \\
\hline $\begin{array}{l}\text { Southern California } \\
\text { Bight }\end{array}$ & Tintinnids & WC & Annual & EL & $4-20 d^{-1}$ & $\begin{array}{l}\text { Heinbokel \& Beers } \\
(1979)\end{array}$ \\
\hline Saanich Inlet & Ciliates \& nauplii & WC & Winter & EL & $30 d^{-1}$ & $\begin{array}{l}\text { Takahashi \& Hoskins } \\
(1978)\end{array}$ \\
\hline Akkeshi Bay & $\begin{array}{l}\text { Total } \\
\text { microzooplankton }\end{array}$ & WC & Annual & EL & $10 \mathrm{yr}^{-1}$ & Taguchi (1976) \\
\hline Long Island Sound & Tintinnids & $\begin{array}{l}0 \mathrm{~m} \\
1 \% \text { light } \\
17 \mathrm{~m}\end{array}$ & Jun-Nov & SF & $12-21 \mathrm{~d}^{-1}$ & $\begin{array}{l}\text { Capriulo \& Carpenter } \\
(1980)\end{array}$ \\
\hline Coastal Washington & $\begin{array}{l}\text { Total } \\
\text { microzooplankton }\end{array}$ & $3 \mathrm{~m}$ & Oct & $\mathrm{SD}$ & $17-52 d^{-1}$ & $\begin{array}{l}\text { Landry \& Hassett } \\
(1982)\end{array}$ \\
\hline Southampton Estuary & Tintinnids & WC & Annual & EL & $60 \mathrm{yr}^{-1}$ & Burkill (1982) \\
\hline Long Island Sound & Tintinnids & $\begin{array}{l}1 \mathrm{~m} \\
5 \mathrm{~m}\end{array}$ & Annual & EL & $27 \mathrm{yr}^{-1}$ & $\begin{array}{l}\text { Capriulo \& Carpenter } \\
\text { (1983) }\end{array}$ \\
\hline Gullmar Fjord & Tintinnids \& rotifers & WC & Annual & $\mathrm{EL}$ & $100 \mathrm{~d}^{-1}$ & Hernroth (1983) \\
\hline Narragansett Bay & Tintinnids & $0 \mathrm{~m}$ & Annual & $\mathrm{SF}$ & $62 \mathrm{yr}^{-1}$ & Verity (1986) \\
\hline Celtic Sea & $\begin{array}{l}\text { Total } \\
\text { microzooplankton }\end{array}$ & WC & Annual & $\mathrm{SD}$ & $13-65 \mathrm{~d}^{-1}$ & Burkill et al. (1987) \\
\hline Jones Sound & $\begin{array}{l}\text { Total } \\
\text { microzooplankton }\end{array}$ & WC & Summer & SD & $40-114 d^{-1}$ & Paranjape (1987) \\
\hline Baffin Bay & $\begin{array}{l}\text { Total } \\
\text { microzooplankton }\end{array}$ & WC & Summer & $\mathrm{SD}$ & $37-88 d^{-1}$ & Paranjape (1987) \\
\hline Halifax Harbour & $\begin{array}{l}\text { Total } \\
\text { microzooplankton }\end{array}$ & $1.5 \mathrm{~m}$ & Annual & SD & $0-100 d^{-1}$ & Gifford (this study) \\
\hline
\end{tabular}

\section{LITERATURE CITED}

Andersen, P., Sorensen, H. M. (1986). Population dynamics and trophic coupling in pelagic microorganisms in eutrophic coastal waters. Mar. Ecol. Prog. Ser. 33: 99-109

Bartram, W. B. (1980). Experimental development of a model for the feeding of neritic copepods on phytoplankton. J. Plankton Res. 3: 25-51

Beers, J. R., Reid, F. M. H., Stewart, G. L. (1975). Microplankton of the North Pacific Central Gyre. Population structure and abundance, June, 1973. Int. Revue ges. Hydrobiol. 60: $607-638$

Beers, J. R., Reid, F. M. H., Stewart, G. L. (1980). Microplankton population structure in southern California nearshore waters in late spring. Mar Biol. 60: 607-683

Beers, J. R., Stevenson, M. R., Epply, R. W., Brooks, E. L. (1971). Plankton populations and upwelling off the coast of Peru, June 1969. Fish. Bull. U.S. 69: 859-876

Beers, J. R., Stewart, G. L. (1969b). Microzooplankton and its abundance relative to the larger zooplankton and other seston components. Mar Biol. 4: 182-189

Beers, J. R., Stewart, G. L. (1970). The ecology of the plankton off LaJolla, California in the period April-Sept., 1967
Part VI. Numerical abundance and estimated biomass of microzooplankton. Bull. Scripps Instn Oceanogr. (New Ser.) $17 \cdot 67-87$

Beers, J. R., Stewart, G. L. (1971). Microzooplankton in the plankton communities of the upper waters of the eastern tropical Pacific. Deep Sea Res. 18: 861-883

Borror, A. C. (1973). Marine flora and fauna of the northeastern United States. Protozoa. Ciliophora. NOAA Tech. Rep. NMFS Circ. 378

Børsheim, K. Y (1984). Clearance rates of bacteria-sized particles by freshwater ciliates measured with monodisperse fluorescent latex beads. Oecologia (Berl.) 63: 286-288

Burkill, P. H. (1982). Ciliates and other microzooplankton components of a near-shore food web: standing stocks and production processes. Annls Inst. océanogr., Paris 58 (S): $335-349$

Burkill, P. H., Mantoura, R. F. C., Llewellyn, C. A., Owens, N. J. P. (1987). Microzooplankton grazing and selectivity of phytoplankton. Mar. Biol. 93: 581-590

Campbell, L., Carpenter, E. J. (1986). Estimating the grazing pressure of heterotrophic nanoplankton on Synechococcus spp. using the seawater dilution and selective inhibitor techniques. Mar. Ecol. Prog. Ser 33: 121-129 
Capriulo, G. M., Carpenter, E. J. (1980). Grazing by 35 to $202 \mu \mathrm{m}$ microzooplankton in Long Island Sound. Mar. Biol. 56: $319-326$

Capriulo, G. M. Carpenter, E. J. (1983). Abundance, species composition and feeding impact of tintinnid microzooplankton in central Long Island Sound. Mar Ecol. Prog. Ser. 10: $277-288$

Conover, R. J., Durvasula, R., Roy, S., Wong, R. (1986). Possible loss of chlorophyll-derived pigments during passage through the gut of zooplankton, and some consequences. Limnol. Oceanogr 31: 878-887

Corliss, J. O. (1979). The ciliated Protozoa. Pergamon Press. New York

Cosper, E., Stepien, J. C. (1984). Phytoplankton-zooplankton coupling in the outer continental shelf and slope waters of the Mid-Atlantic Bight, June 1979. Estuar. coast. Shelf Sci. 18: 145-155

Fauré-Fremiet, E. (1924). Contribution à la connaissance des infusoires planktoniques, Bull. Biol. Fr. Belg. 6 (Suppl.): $1-171$

Fenchel, T. (1980). Relation between particle size selection and clearance in suspension feeding ciliates. Limnol. Oceanogr. 25: 733-738

Frost, B. W. (1972). Effects of size and concentration of food particles on the feeding behavior of the marine planktonic copepod, Calanus pacificus. Limnol. Oceanogr. 17 . 805-815

Fuhrman, J. A., McManus, G. B. (1984). Do bacteria-sized marine eukaryotes consume significant bacterial production? Science 224: 1257-1260

Gifford, D. J. (1985a). The impact of grazing and growth of marine planktonic oligotrichs (Ciliophora: Oligotrichida) in laboratory culture and in the Northwest Arm of Halifax Harbour. Ph. D. thesis, Dalhousie Univ., Halifax

Gifford, D. J. (1985b). Laboratory culture of marine planktonic oligotrichs (Ciliophora; Oligotrichida). Mar Ecol. Prog. Ser. 23: 257-267

Gifford, D. J., Bohrer, R. N., Boyd, C. M. (1981). Spines on diatoms: do copepods care? Limnol. Oceanogr 26: 1057-1061

Gifford, D. J., Dagg, M. J. (1988). Feeding of the estuarine copepod, Acartia tonsa Dana: carnivory vs. herbivory in natural microplankton assemblages. Bull. mar Sci. (in press)

Goldman, J. C., Caron, D. A. (1985). Experimental studies on an omnivorous microflagellate: implications for nutrient regeneration in the marine microbial food chain. Deep Sea Res. 32: 899-915

Heinbokel, J. F. (1978a). Studies on the functional role of tintinnids in the Southern California Bight. I. Grazing and growth rates in laboratory cultures. Mar. Biol. 47: 177-189

Heinbokel, J. F. (1978b). Studies on the functional role of tintinnids in the Southern California Bight. II. Grazing rates of field populations. Mar. Biol. 47: 191-197

Heinbokel, J. F., Beers, J. R. (1979). Studies on the functional role of tintinnids in the Southern California Bight. III. Grazing impact of natural assemblages. Mar. Biol. 52: 23-32

Hernroth, L. (1983). Marine pelagic rotifers and tintinnids important trophic links in the spring plankton community of the Gullmar Fjord, Sweden. J. Plankton Res. 5: 835-846

Johansen, P. L. (1976). A study of tintinnids and other Protozoa in eastern Canadian waters with special reference to feeding, nitrogen excretion and respiration rates. Ph. D. thesis, Dalhousie Univ., Halifax

Kahl, A. (1932). Urtiere oder Protozoa. I. Wimpertiere oder Ciliate (Infusoria). 3. Spirotricha; 2. Unterorderung Oligo- tricha Butschli, 1889. In: Dahl, F. (ed.) Die Tierwelt Deutschlands 25: 487-513

Kiørboe, T., Tiselius, P. T. (1987). Gut clearance and pigment destruction in a herbivorous copepod, Acartia tonsa, and the determination of in situ grazing rates. J. Plankton Res. 9: $525-534$

Klien, B., Gieskes, W W. C., Kraay, G. G. (1986). Digestion of chlorophylls and carotenoids by the marine protozoan Oxyrrhis marina studies by h.p.l.c. analysis of algal pigments. J. Plankton Res. 8: 827-836

Lam, R. K., Frost, B. W. (1976). Model of copepod filtering response to changes in size and concentration of food. Limnol. Oceanogr. 21: 490-500

Landry, M. R., Hassett, R. P. (1982). Estimating the grazing impact of marine microzooplankton. Mar. Biol. 67: 283-288

Lessard, E. J. (1984). Oceanic heterotrophic dinoflagellates: distribution, abundance and role as microzooplankton. Ph. D. thesis, Univ. of Rhode Island, Kingston

Lessard, E. J., Swift, E. (1985). Species-specific grazing rates of heterotrophic dinoflagellates in oceanic waters, measured with a dual-label radioisotope technique. Mar. Biol. 87: 289-296

Li, W. W. K., Dickie, P. M. (1985). Growth of bacteria in seawater filtered through $0.2 \mu \mathrm{m}$ Nucleopore membranes: implications for dilution experiments. Mar. Ecol. Prog. Ser. 26: $245-252$

Lindholm, T (1985). Mesodinium rubrum - a unique photosynthetic ciliate. Adv. aquat. Microbiol. 3: 1-48

Marshall, S. M. (1969). Protozoa. Order: Tintinnida. In: Fraser, J. H., Hensen, V Kr. (eds.) Fiches d'identification du zooplankton. Cons perm int Explor. Mer, Charlottenlund, No. $117-127$

McManus, G. B., Fuhrman, J. A. (1986). Photosynthetic pigments in the ciliate Laboea strobila from Long Island Sound, USA. J. Plankton Res. 8: 317-237

Paranjape, M. A. (1987). Grazing by microzooplankton in the eastern Canadian arctic in summer 1983. Mar Ecol. Prog. Ser. 40: 239-246

Paranjape, M. A., Conover, R. J., Harding, G. C., Prouse, N. J. (1985). Micro- and macrozooplankton on the Nova Scotian shelf in the prespring bloom period: a comparison of their potential resource utilization. Can. J. Fish. Aquat. Sci. 42: 1484-1492

Nival, P., Nival, S. (1976). Particie retention efficiencies of an herbivorouis copepod, Acartia clausi (adult and copepodite stages) effects on grazing. Limnol. Oceanogr 21. $24-38$

Perry, M. J., Talbot, M. K., Alberte, C. S. (1981). Photoadaptation in marine phytoplankton: responses of the photosynthetic unit. Mar. Biol. 62: 91-101

Prezélin, B. B. (1976). The role of peredinin-chlorophyll proteins in the photosynthetic light-adaptation of the marine dinoflagellate Glenodinium sp. Planta 130: 233-255

Rassoulzadegan, F. (1982). Dependence of grazing rate, gross growth efficiency, and the food size range on temperature in a pelagic oligotrichous ciliate, Lohmanniella spiralis Leeg., fed on naturally occurring particulate matter. Annls Inst. océanogr., Paris 58: 177-184

Rassoulzadegan, F., Etienne, M. (1981). Grazing rate of the tintinnid Stenosomella ventricosa (Clap. et Lach.) Jorg. on the spectrum of the naturally occurring particulate matter from a Mediterranean neritic area. Limnol. Oceanogr. 26: 2258-2270

Riley, G. A. (1956). Oceanography of Long Island Sound, 1952-1954. IX. Production and Utilization of Organic Matter. Bull. Bingham Oceanogr. Collect. Yale University 15: $324-341$ 
Robertson, J. R. (1983). Predation by estuarine zooplankton on tintinnid ciliates. Estuar coast. Shelf Sci. 16: 27-36

Sheldon, R. W. Nival, P., Rassoulzadegan, F. (1986). An experimental investigation of a flagellate-ciliate-copepod food chain with some observations relevant to the linear biomass hypothesis. Limnol. Oceanogr. 31. 184-188

Sherr, E. B., Sherr, B. F. (1987). High rates of consumption of bacteria by pelagic ciliates. Nature, Lond. 325: 710-711

Sherr, B. F., Sherr, E. B., Andrew, T L., Fallon, R. D., Newell S. Y. (1986). Trophic interactions between heterotrophic Protozoa and bacterioplankton in estuarine water analyzed with selective metabolic inhibitors. Mar. Ecol. Progr. Ser. 32: 169-179

Smetaček, V. (1981). The annual cycle of the protozooplankton in Kiel Bight. Mar. Biol. 63: 1-11

Sokal, R. R., Rohlf, F. J. (1981). Biometry: the principles and practice of statistics in biological research. W. H. Freeman \& Co., San Francisco

SooHoo, J. B., Kiefer, D. A. (1982). Vertical distribution of phaeopigments. I. A simple grazing and photooxidative scheme for small particles. Deep Sea Res. 29: 1539-1551

Spittler, P. (1973). Feeding experiments with tintinnids. Oikos 15 (Suppl.): 128-132

Stoecker, D. K., Egloff, D. (1987). Predation by Acartia tonsa Dana on planktonic ciliates and rotifers. J. exp. mar. Biol. Ecol. 110: 53-68

Stoecker, D. K., Guillard, R. R. L., Kavee, R. M. (1981). Selective predation by Favella ehrenbergii (Tintinnina) on and among dinoflagellates. Biol. Bull. mar. biol. Lab., Woods Hole 160: 136-145

Stoecker, D. K., Michaels, A. E., Davis, L. H. (1987). Large proportion of marine planktonic ciliates found to contain functional chloroplasts. Nature, Lond. 326: 790-792

Stoecker, D. K., Sanders, N. K. (1985). Differential grazing by Acartia tonsa on a dinoflagellate and a tintinnid. J. Plankton Res. 7: 85-100

Strickland, J. D. H., Parsons, T R. (1972). A practical hand- book of seawater analysis. Fish. Res. Bd Can. Bull. 167 (2nd edn, Ottawa)

Taguchi, S. (1976). Microzooplankton and seston in Akkeshi Bay, Japan. Hydrobiologia 50: 195-204

Takahashi, M., Hoskins, K. D. (1978). Winter conditions of marine plankton populations in Saanich Inlet, B. C. Canada. II. Microzooplankton. J. exp. mar. Biol. Ecol. 32: $27-37$

Taylor, G. T., Pace, M. L. (1987). Validity of eukaryote inhibitors for assessing production and grazing mortality of marine bacterioplankton. Appl. environ. Microbiol. 53: $119-128$

Throndsen, J. (1978). Preservation and storage. In: Sournia, A. (ed.) Phytoplankton Manual. UNESCO, Paris, p. 69-74

Tremaine, S. C., Mills, A. L. (1987). Inadequacy of eukaryote inhibitor cycloheximide in studies of protozoan grazing on bacteria at the freshwater-sediment interface. Appl. environ. Microbiol. 53: 1969-1972

Turner, J. T., Anderson, D. M. (1984). Zooplankton grazing during dinoflagellate blooms in a Cape Cod embayment, with observations of predation upon tintinnids by copepods. P. S. Z. N. Mar. Ecol. 4: 359-374

Verity, P. G. (1985). Grazing, respiration, excretion and growth rates of tintinnids. Limnol. Oceanogr. 30: 1268-1282

Verity, P. G. (1986). Grazing of phototrophic nanoplankton by microzooplankton in Narragansett Bay. Mar. Ecol. Prog. Ser. 29: 105-115

Verity, P. G., Villareal, T. A. (1986). The relative food value of diatims, dinoflagellates, flagellates and cyanobacteria for tintinnid ciliates. Arch. Protistenk. 131: 71-84

Wang, R., Conover, R. J. (1986). Dynamics of gut pigment in the copepod Temora longicornis (Muller) and the determination of in situ grazing rates. Limnol. Oceanogr. 31. 867-877

Welschmeyer, N. A., Lorenzen, C. J. (1985). Chlorophyll budgets: zooplankton grazing and phytoplankton growth in a temperate fjord and in the Central Pacific Gyre. Limnol. Oceanogr. 30: 1-21 